\title{
Autumn and winter kidney fat indexes of roe deer does and their correlation with reproductive parameters
}

\author{
István Majzinger \\ University of Szeged, Faculty of Agriculture, Institute of Animal Sciences and Game Management, Hódmezővásárhely \\ mi@mgk.u-szeged.hu
}

SUMMARY

\begin{abstract}
I studied the variations of kidney fat indexes (KFI) in two game management units of the Great Hungarian Plain between 2002 and 2004 in the autumn and winter months. I was looking for correlation between the autumn and winter KFI as well as between the autumn KFI and reproductive parameters (number of corpora lutea, recruitment rate).

There was a significant positive correlation between the average winter and the average next autumn KFI $(r=0.991, p<0.1)$. The average winter KFI showed strong positive correlation with the average number of corpora lutea $(C L)$ in the next rutting season ( $r=0.978$, $p<0.05)$. The average autumn KFI and the average grown up offspring showed positive but not significant correlation $(r=0.725, p=0.275)$.
\end{abstract}

Keywords: condition, kidney fat index in autumn, KFI in winter, number of corpora lutea, recruitmet, grown up progeny

\section{ÖSSZEFOGLALÁS}

Két alföldi vadászterületen vizsgáltam az özsuták vesezsír-indexének alakulásátaz az öszi és téli időszakban 2002 és 2004 között. A vizsgálat egyrészt az öszi és téli kondició közötti, másrészt az öszi kondició és a szaporodási paraméterek (sárgatest zsám, felnevelt szaporulat) közötti esetleges kapcsolat felfedését célozta.

Pozitív szignifikáns kapcsolat adódott a téli és a következö év öszi vesezsir-indexe között $(r=0,991 ; p<0,1)$. Az átlagos téli vesezsir-index és a következö szaporodási időszak átlagos sárgatest száma között erős pozitív korreláció volt kimutatható( $r=0,978 ; p<0,05)$. Az átlagos öszi vesezsir-index és a felnevelt szaporulat között pozitív, de nem szignifikáns kapcsolat volt $(r=0,725 ; p=0,275)$.

Kulcsszavak: kondició, öszi vesezsír-index, téli vesezsir-index, sárgatest szám, szaporulat, felnevelet szaporulat

\section{INTRODUCTION}

One feature of the metabolism of the roe deer is that during the winter months there are less nutrients built in, which coincides with the decrease of the quantity of the accessible food (McEwan and Whitehead, 1970). This mechanism is presumably of an adaptive character, and in this way the pregnant does save energy for the time of the adverse environmental conditions. The changes affecting the ingestion (appetite), the growth and the intensity of the metabolism might depend on the management of the endocrine system. (Seal et al., 1972). Considering the populations living in the neighbourhood of the northern border the seasonal changes of the fat reserves are explained by the special reproductive characteristics of the roe, which is exceptional among the deer species. It means the maximum of the reproductive input is long before winter in case of both sexes (mating in case of the males and kidding in case of the females) The demolition phase begins at the beginning of January and ends in April in both sexes. Fat reserves accumulation took place in September and October (Holand, 1992).

Because of the embryonic diapause, the real energydemanding phase of the pregnancy begins in FebruaryMarch, but its culmination coincides with the abundant supply of food of vegetation (the author's comment). At the same time Holand (1992) experienced a fat reserves decrease in populations in Norway, despite the less intensive winter metabolism substances the decreases a winter basal metabolism. Hewison et al. (1996) in France (Dourdan forest) found the seasonal kidney fat index different in every age group, while there was no difference according to sex.
In the kids, just like in the young (2-year-old), the kidney fat index decreased all winter from the maximum values measured in November-December and this tendency continued in the remaining period until they reached the age of two. An increase in kidney fat index could be seen in the adults from August till November, furthermore, unlike in case of the young, it was not decreasing in the winter month, on the contrary, it kept on increasing till the peak in February. Between February and April could see a sharp decrease (mostly in the bucks) and this process continued as long as August. Ratcliffe (1980) thinks it proves the winter could be a critical period for the kids and the young animals from an energetics viewpoint. This is also proved by the fact that the rate of an appreciated metabolism of the kids is $25 \%$ higher than that of the adults. Therefore they might be more sensitive to the environmental stress (e.g. long winter cold) (Drodz et al., 1975 cit: Hewison et al., 1996). Thus in the above experiment - contrary to the previous results of Holand (1992) - the kidney fat index did not decrease between November and April, except in the young, but the weather conditions were much more favourable and the food supply was much more ample in this period of the examination than usual. It seems the roe deer use their fat reserves in an optional manner depending on the climate and nutritional conditions (Drodz et al., 1975 cit: Hewison et al., 1996).

In the case of most deer species asynchrony can be seen between the sexes in the cyclical changes of the body composition and the condition (Anderson et al., 1990). The results of Holand (1992) prove there is no asynchrony in the roe deer in the reproductive period 
since it is culminated in the spring and summer months in both sexes. It is the period of territory sustenance and mating for bucks and the last period of pregnancy, the time of kidding and milking for does. In winter the pregnancy is not very demanding for does because of the embryonic diapause. The maximum of the energy consumption of does falls in the summer months, which is reflected in cycle of the condition within a year. (Hewison et al., 1996). Weiner (1977) proved that the metabolic rate of does increased more than twice as much during the milk production period, which resulted in an average of $1.5 \mathrm{~kg}$ live weight loss. Hewison et al. (1996) assume the seasonal changes of the body weight and the condition are a combination of an internal rhythm and a high reproduction activity input. In early spring the metabolic rate that was low in winter increases; both the bucks and the does start mobilise their fat reserves left from winter, which was accumulated in autumn. Between April and August the does keep on using their fat reserves in the last stage of pregnancy and the first two months of lactation and their body weight decreases considerably. The fat reserves of the bucks decreases in early spring and it is rather low at the beginning of the mating period (Drodz et al., 1975 cit: Hewison et al., 1996).

Concerning the body condition and reproduction performance Farkas (1985) claims there is a definite correlation between the body condition of the doe and the number of embryos; $75 \%$ of the does in good body condition had twins, while this was only $53 \%$ in the does in poor body condition. $14 \%$ of the good-conditioned and $21 \%$ of the bad-conditioned proved to be empty. Consequently the good body condition improves fertility, at the same time it might be varied according to habitats and years. Monostori (1999) published similar results saying that the increase of population density resulted in a decrease of body weight and the deterioration of body condition. As a consequence the reproductive performance decreased, which was realised in the decrease of the embryo number and the number of grown up progeny. However we can observe that the improvement in the body condition of the does results in a slight increase in the number of corpora lutea and also the embryo number, even in fairly consolidated environmental conditions (Majzinger, 2006).

\section{MATERIAL AND METHOD}

The data, on which the research is based, are from the roe deer does observed and 274 roe deer does having been shot on the territories of three hunting units on the Hungarian Plain in the hunting season of 2002/2003 (hereinafter 2002), 2003/2004 (hereinafter 2003) and 2004/2005 (hereinafter 2004). Territories:

- Hódmezővásárhely (hunting unit area is 27400 ha): intensive cultivated agricultural land with large corn fields dominating. Forest cover $0.9 \%$ and the quality of the roe deer population here is qualified as ,good". The population density is (reported) 3.4 roe deer $100 \mathrm{ha}^{-1}$.

- Nagyszénás (hunting unit area is 16800 ha): intensive cultivated agricultural land with different field sizes. Forest cover $1.3 \%$ and the quality of the roe deer population here is qualified as ,excellent”. The population density is (reported) 4.6 roe deer $100 \mathrm{ha}^{-1}$.
The body condition was determined by kidney fat index calculation (Sugár, 1983), when I weighed the kidney and the fat around the kidney, respectively. I calculated the kidney fat index with the method of Caughley and Sinclair (1994): KFI = the weight of the fat around the kidney / the weight of the kidney.

I determined the number of CL by cutting through the ovaries in several sections. The number of the grown up progeny was estimated in the territory between November and January.

The age of the does was estimated on the basis of their tooth wear by cementum-layer counting, which I carried out with the method of Aitken (1975) on the last M1 molar tooth. I distinguished three age groups: young (1-year-old, see age group 1.), adult (2-7 yearold, see age group 2.) and old (8-year-old and over 8 year-old, see age group 3.).

For data procession I applied the SPSS for Windows (11.0.0. Standard Version) statistical programme.

\section{RESULTS}

The KFI of the roe deer does shot in the hunting season of 2002 was increasing or at least stagnant between October and December. Because of the unusually severe snowy winter no roe deer was shot in either territories in January. Compared to the December values the average February KFI fell back to the minimum level on both (Hódmezővásárhely and Nagyszénás) territories (table 1, figure 1).

In the hunting season of 2003 the October KFI were relatively low in all two regions, but in the following few months they showed a tendency of increasing, although with some fluctuation. By the end of winter the February KFI-es were significantly higher than in the previous February.

In the hunting season of 2004 the average KFI in October-November was higher than that of the same period in the previous year. At the same time the condition did not change or slightly decreased in January and it did not fall back to (nor even come near) the minimum level of the hunting season of 2002 (February 2003) in the Nagyszénás region.

The KFI did not show significant differences between the animals by yearly age, so I examined the above mentioned three age-groups in the whole period of 2002-2004.

The tendency of the KFI changes of the three agegroups do not show significant difference in two regions (figure 2). From October to November the body condition improved in all age groups. We could observe a considerable condition loss only in the does belonging to age-group 3 (old) shot in Nagyszénás in December. Between November and January, with the different levels of KFI in different regions and in different age groups, the condition of the does hardly decreased.

It was in January and February that the KFI fell back everywhere. Among the adult does of age-group 2 the condition was almost the same in the examined period. The data of the young does (age-group 1) are also similar, apart from the fact that we have no data from Nagyszénás from February. The kidney fat changes of old does showed higher fluctuation in Hódmezővásárhely, while the tendency is the same on both territories in the period between October and January 
Monthly average KFI in does

\begin{tabular}{|c|c|c|c|c|c|c|c|c|c|c|c|c|c|c|c|c|}
\hline & \multicolumn{3}{|c|}{ October } & \multicolumn{3}{|c|}{ November } & \multicolumn{3}{|c|}{ December } & \multicolumn{3}{|c|}{ January } & \multicolumn{3}{|c|}{ February } \\
\hline & & $\mathrm{N}$ & $x$ & $\mathrm{CV}_{\%}$ & $\mathrm{~N}$ & $x$ & $\mathrm{CV}_{\%}$ & $\mathrm{~N}$ & $x$ & $\mathrm{CV}_{\%}$ & $\mathrm{~N}$ & $x$ & $\mathrm{CV}_{\%}$ & $\mathrm{~N}$ & $x$ & $\mathrm{CV}_{\%}$ \\
\hline \multirow{4}{*}{$\mathrm{Hmv}$} & 2002 & - & - & - & 4 & 1.16 & 19.6 & 4 & 1.69 & 15.4 & - & - & - & 5 & 0.30 & 67.7 \\
\hline & 2003 & 35 & 0.74 & 66.2 & 5 & 1.67 & 34.1 & 3 & 2.15 & 4.6 & 10 & 1.22 & 72.9 & 8 & 1.67 & 39.5 \\
\hline & 2004 & 3 & 1.70 & 32.3 & 9 & 2.02 & 36.6 & 5 & 1.74 & 56.9 & 13 & 1.77 & 40.7 & 17 & 1.25 & 56.0 \\
\hline & All; Average & 38 & 0.82 & 68.3 & 18 & 1.73 & 39.3 & 12 & 1.83 & 35.5 & 23 & 1.53 & 54.2 & 30 & 1.20 & 63.3 \\
\hline \multirow{4}{*}{ Nsz } & 2002 & - & - & - & 32 & 0.87 & 56.3 & 4 & 0.83 & 60.7 & - & - & - & 5 & 0.19 & 73.7 \\
\hline & 2003 & 23 & 0.71 & 70.4 & 51 & 1.13 & 48.7 & 5 & 0.84 & 53.6 & 10 & 1.03 & 51.4 & 2 & 1.44 & 14.6 \\
\hline & 2004 & - & - & - & 7 & 1.46 & 42.4 & 9 & 1.64 & 48.8 & 5 & 1.48 & 12.2 & - & - & - \\
\hline & All; Average & 23 & 0.71 & 70.4 & 90 & 1.06 & 52.3 & 18 & 1.24 & 60.5 & 15 & 1.18 & 41.5 & 7 & 0.55 & 90.5 \\
\hline
\end{tabular}

Hmv = Hódmezővásárhely, Nsz = Nagyszénás

Figure 1: KFI in does in the examined regions $(\mathbf{p}=\mathbf{0 . 0 5})$
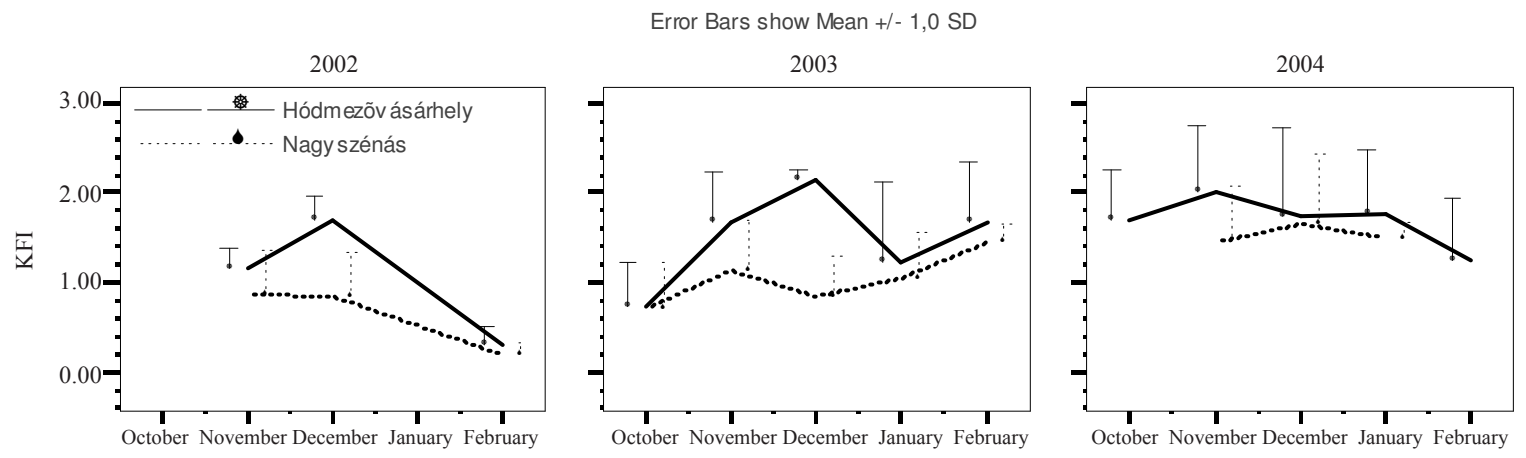

Figure 2: Average KFI in does of various age groups in the examined regions $(\mathbf{p}=\mathbf{0 . 0 5})$
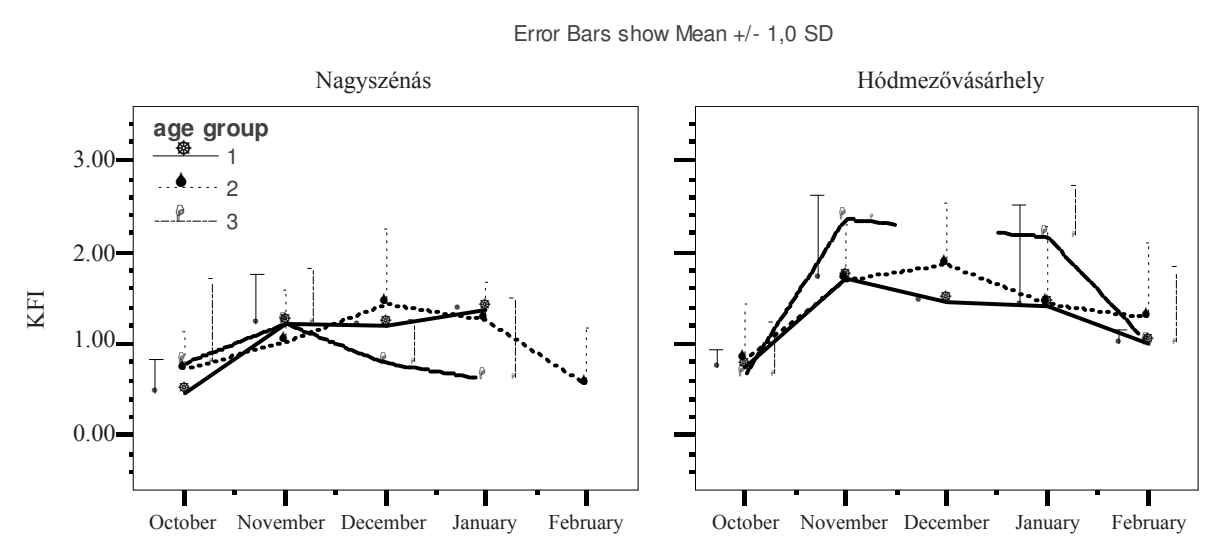

To examine the correlation with reproductive parameters I used the autumn and winter KFI since the two periods are totally different in terms of body condition under unfavourable environmental conditions. It means the fat depots filled in autumn (AugustNovember) can be mobilised in January-February (Drodz et al., 1975 cit: Hewison et al., 1996) and the KFI can decrease considerably. This setback can not be observed in a mild winter and in case of ample food supply. I presume that such changes of the body condition might have correlation with certain reproductive parameters, e.g. the autumn body conditions with the grown-up progeny. Figure 1 also shows it is likely the late winter body condition has correlation with the body condition level of the following autumn. I calculated the autumn body condition from the KFI of the does shot in October-November-December, while the winter body

condition from the data of the does shot in JanuaryFebruary (table 2).

The average winter KFI has a close positive correlation with the average KFI in the following autumn $(\mathrm{r}=0.991 ; \mathrm{p}<0.1)$ (table 3, figure 3).

The average number of CL and the average winter KFI are also in close positive correlation $(\mathrm{r}=0.978$, $\mathrm{p}<0.05$ ) (table 3, figure 4). Presumably the winter body condition has an effect on the body condition at the time of the next rutting period and in this way indirectly the ovulation rate indicated by the number of CL.

The average autumn KFI shoes a moderately positive - not significant - correlation between the average grown-up progeny $(\mathrm{r}=0.732, \mathrm{p}=0.160)$ (table 3 , figure 5 ), at the same time there is no rateable correlation with the previous winter body condition $(r=0.385, p=0.451)$. 
Average KFI and reproductive parameters

\begin{tabular}{lccccc}
\hline & & KFI (autumn) & KFI (winter) & Number of CL & Grown up progeny \\
\hline \multirow{3}{*}{ Hódmezővásárhely } & 2002 & 0.95 & 0.30 & 1.84 & 1.17 \\
& 2003 & 1.88 & 1.42 & 2.17 & 1.57 \\
& 2004 & - & 1.47 & - & 1.33 \\
\hline \multirow{3}{*}{ Nagyszénás } & 2002 & 0.99 & 0.19 & 1.42 & 0.75 \\
& 2003 & 1.56 & 1.10 & 2.00 & 1.04 \\
& 2004 & - & 1.48 & - & 0.76 \\
\hline
\end{tabular}

Table 3.

The correlation of KFI and reproductive parameters

\begin{tabular}{lll}
\hline & KFI (autumn) & \multicolumn{1}{c}{ KFI (winter) } \\
\hline KFI (winter) & $\mathrm{r}=0.991(\mathrm{p}<0.1)$ & - \\
Number of CL & $\mathrm{r}=0.997(\mathrm{p}<0.01)$ & $\mathrm{r}=0.978(\mathrm{p}<0.05)$ \\
Grown up progeny & $\mathrm{r}=0.725(\mathrm{p}=0.275) *$ & $\mathrm{r}=0.385(\mathrm{p}=0.451)^{*}$ \\
\hline
\end{tabular}

$*=$ not significant

Figure 3: The correlation between the winter (JanuaryFebruary) KFI and the next autumn (October-December) KFI in 2002-2004

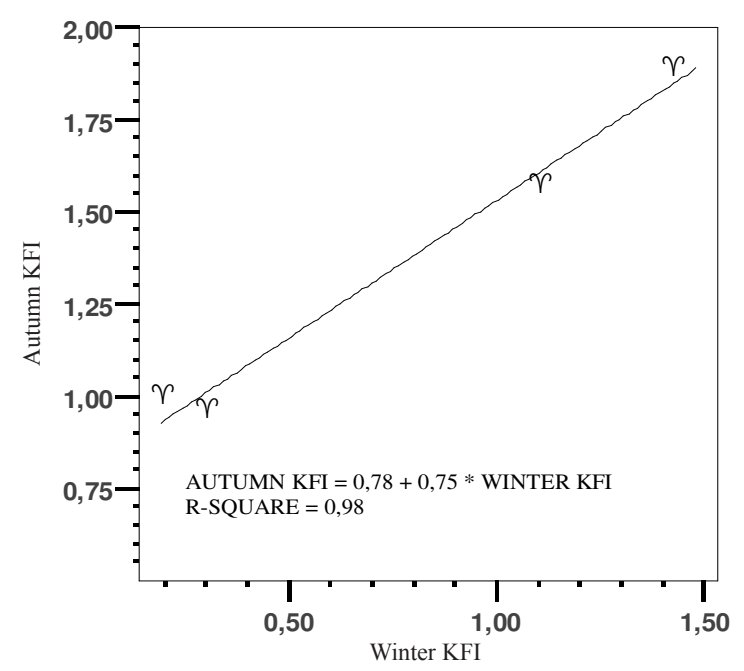

Figure 4: The correlation between the winter (JanuaryFebruary) KFI indexes and the number of CL in 2002-2004

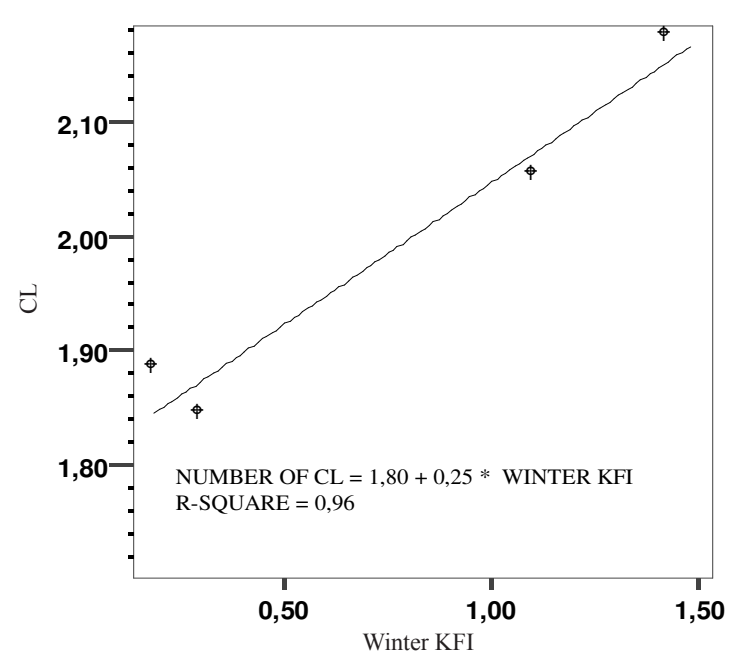

Figure 5: The correlation between the autumn (OctoberDecember) KFI and the grown up progeny in 2002-2004

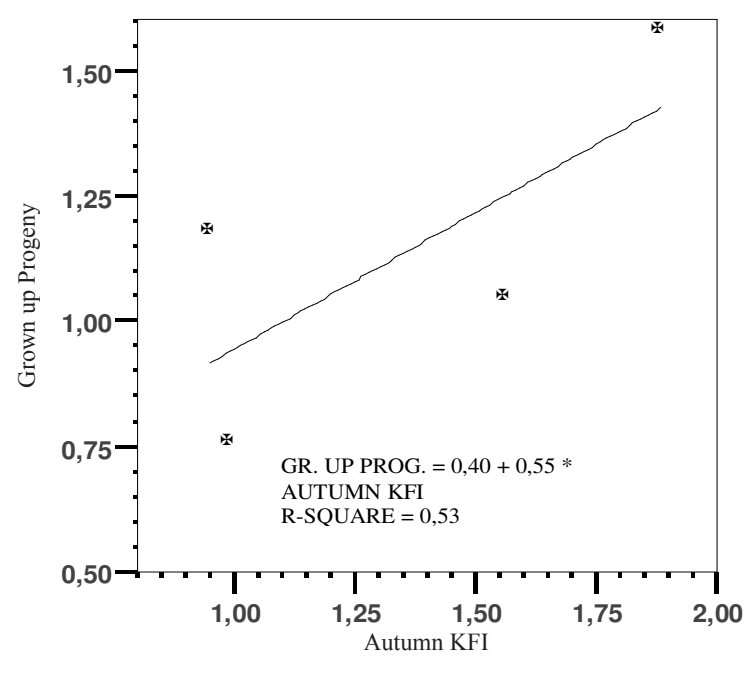

The winter body condition of the does is the indicator of the quality of the environment (food, calmness), which is in connection with the success of rearing the kids. In this way the quality of the environment is the link between the body condition of the does (e.g. more milk) and the number of the grown-up progeny.

\section{CONCLUSIONS}

The KFI in the autumn and winter months, although the levels are different by territories, show similar tendencies in a several ways. The fat accumulated in late summer and in autumn (not in extremely severe winter weather conditions) does not decrease visibly. On the contrary, it might happen it stagnates or perhaps increases until the end of winter.

The examinations of Hewison et al. (1996) found similar dynamics in the KFI of adult roe deer in France, which is related to the specific winter metabolism intensity decrease of the roe deer. (McEwan and Whitehead, 1970; Seal et al., 1972). The fat reserve mobilisation 
and the decrease of the KFI can be seen when the winter conditions are excessively unfavourable (the winter of 2002-2003).

In the permanency of such conditions the KFI decreases to the minimum level in the whole population, in case of many roe deer the fat around the kidney totally disappears. Probably they also use the fat in the bone marrow, especially the young animals, but I do not examine that during this research. The minimum level of the winter body condition do not reach the level of the same time of the previous year by the end of the following vegetation period (October-November, 2003 the level of October-November, 2002). Nevertheless, if the late winter KFI is high then the KFI in the following autumn will be high as well. To recover from the deteriorated body condition seems to take a longer time and its potential negative consequences have a long term effect (e.g. reproductive performance, antler growth, survival).

The autumn (October-December) body condition of the does indicates the quality of their habitat, of their home territory, which, at the same time, can influence the milk production of the does, through that indirectly the initial growth and survival of the kids. The better quality food supply of the better habitat is a determinative factor of the growth of the kids even after weaning.

\section{REFERENCES}

Anderson, A. E.-Medin, D. E.-Bowden, D. C. (1990): Indexing the annual fat cycle in a mule deer population. J. Wild. Manage. 54: $550-556$.

Caughley, G.-Sinclair, A. R. E. (1994): Wildlife ecology and management. Blackwell Science.

Drodz, A.-Weiner, J.-Gebczynska, Z.-Krasinska, M. (1975): Some bioenergetic parameters of wild ruminant. The role of large herbivorous mammals in functioning of woodland ecosystems. [In: Hewison, A. J. M. et al. (1996): Annual variation in body composition of roe deer (Capreolus capreolus) in moderate environmental conditions. Can. J. Zool. 74. 2: 245-253.] Pol. Ecol. Stud. 1. 2: 85-101.

Farkas D. (1985): Alföldi és dunántúli őzpopulációkban végzett vemhességi vizsgálat. Nimród Fórum. 1985. június 1-4.

Hewison, A. J. M.-Angibault, J. M.-Boutin, J.-Bideau, E.-Vincent, J. P.-Sempéré, A. (1996): Annual variation in body composition of roe deer (Capreolus capreolus) in moderate environmental conditions. Can. J. Zool. 74. 2: 245-253.

Holand, Ø. (1992): Seasonal variation in body composition of European roe deer. Can. J. Zol. 70: 502-504.
Majzinger I. (2006): Az őz (Capreolus capreolus) szaporodási teljesítményének vizsgálata különböző típusú mezei élőhelyeken. Debreceni Egyetem Mezőgazdaságtudományi Kar. Doktori (Ph.D.) disszertáció. 151.

Mc Ewan, E. H.-Whitehead, P. E. (1970): Seasonal changes in energy and nitrogen intake in reindeer and caribou. Can. J. Zool. 48: 905-913.

Monostori L. (1999): Az őzállomány állapotvizsgálatának módszere. Vadászlap. 12-13.

Ratcliffe, P. R. (1980): Bone marrow fat as an indicator of condition in roe deer. Acta Theriol. 25: 333-340.

Seal, U. S.-Verme, L. J.-Ozoga, J. J.-Erickson, A. W. (1972): Nutritional effects on thyreoid activity and blood of white-tailed deer. J. Wild. Manage. 36: 1041-1052.

Sugár L. (1983): A nagyvad tápláltsági állapotának mérése. Nimród Fórum. 10: 10-11

Weiner, J. (1977): Energy metabolism of roe deer. Acta Theriol. 22: $3-24$ 
